\title{
Resilience and community response to climate-related events: Case studies from four countries
}

Aviva Klein Meyers

Karen Hardee

Population Council

Follow this and additional works at: https://knowledgecommons.popcouncil.org/departments_sbsr-rh

Part of the Demography, Population, and Ecology Commons, Family, Life Course, and Society Commons, International Public Health Commons, and the Place and Environment Commons How does access to this work benefit you? Let us know!

\section{Recommended Citation}

Klein Meyers, Aviva and Karen Hardee. 2017. "Resilience and community response to climate-related events: Case studies from four countries," working paper. Washington, DC: Population Council, The Evidence Project. 


\section{Evidence}

\section{Resilience and Community Response} to Climate-related Events

Case Studies from Four Countries

3
0
0
$\frac{1}{7}$
0
0
0
11
0

Aviva Klein Meyers

Karen Hardee

DECEMBER 2017

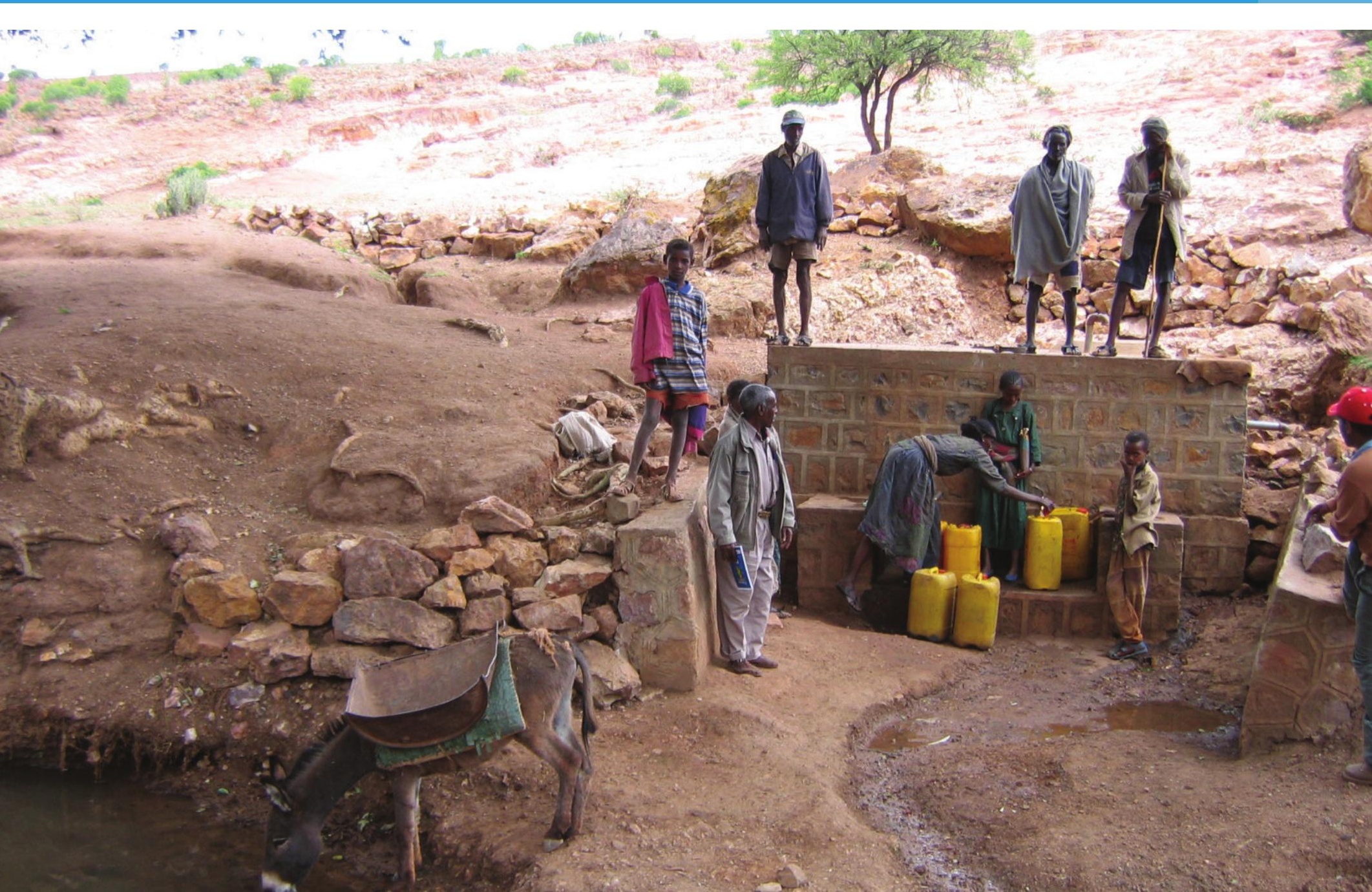



Resilience and Community Response to Climate-related Events

Case Studies from Four Countries

Aviva Klein Meyers

Karen Hardee

DECEMBER 2017 
The Evidence Project is made possible by the generous support of the American people through the United States Agency for International Development (USAID) under the terms of cooperative agreement no. AID-OAA-A-13-00087. The contents of this document are the sole responsibility of the Evidence Project and Population Council and do not necessarily reflect the views of USAID or the United States Government.

\section{Evidence}

The Evidence Project uses implementation science-the strategic generation, translation, and use of evidence-to strengthen and scale up family planning and reproductive health programs to reduce unintended pregnancies worldwide. The Evidence Project is led by the Population Council in partnership with INDEPTH Network, International Planned Parenthood Federation, PATH, Population Reference Bureau, and a University Research Network.

Published in 2017.

Suggested citation: Meyers, Aviva Klein and Karen Hardee. 2017. "Resilience and Community Response to Climate-related Events Case Studies from Four Countries," Working Paper. Washington, DC: Population Council, The Evidence Project.

Photo credit on cover page: @2005 Sandra Kalscheur, Courtesy of Photoshare

(C) 2017. The Population Council, Inc.

\section{Acknowledgments}

This review has benefited from the comments of Clive Mutunga from USAID. The authors also appreciate the review of Kate Gilles of Population Reference Bureau and formatting of Anneka Van Scoyoc, also of the Popualation Reference Bureau, both through the Evidence Project. 


\section{Table of Contents}

LIST OF ACRONYMS ................................................................................ VI

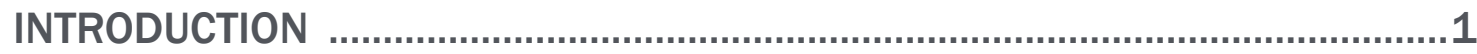

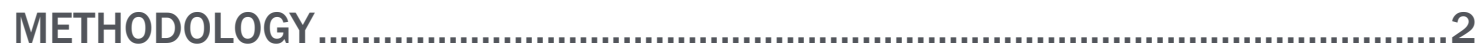

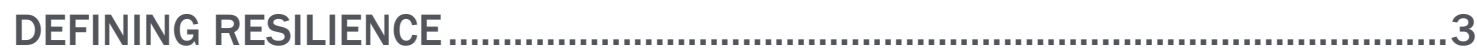

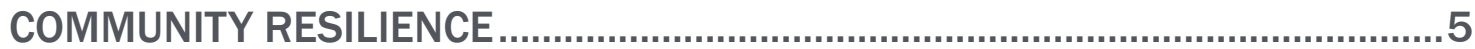

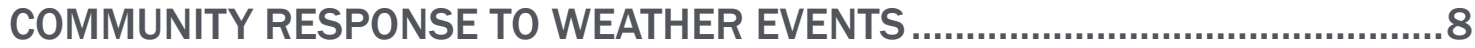

Drought in Ethiopia .......................................................................... 9

Floods in Mozambique ......................................................................... 13

Cyclone in the Philippines ......................................................... 17

Forest Fire in Indonesia....................................................................... 21

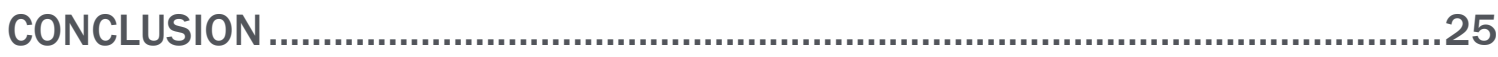

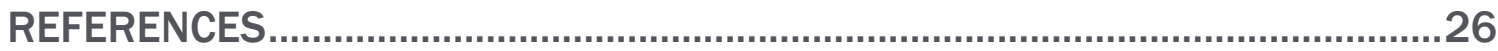




\section{Introduction}

Since 1880, Earth's average global temperature has increased by about $0.8^{\circ}$ Celsius (NASA n.d.). Though it seems a small difference, this warming has led to extreme changes in global climate, with an array of risks for human and environmental systems, including weather events such as heat waves, extreme precipitation, wildfires, cyclones, and coastal flooding. Among the impacts of weather events are the "alteration of ecosystems, disruption of food production and water supply, damage to infrastructure and settlements, morbidity and mortality, and consequences for mental health and human well-being" (Field et al. 2014). The distribution of these impacts is uneven, with disadvantaged and impoverished individuals and communities facing the greatest risk.

With the threat of climate change and related weather events looming over the global community, regardless of development status, it has become a top priority of many nations and communities to prepare for and mitigate the effects of climate change. Terms like disaster risk management, natural resource management, and climate-adaptive practices have become commonplace in legislation and research regarding climate change. In particular, the term "resilience" stands out across discussions about combatting climate change. Though there is some variation in definition, resilience is basically understood as the ability of a system to cope with a hazard by responding in ways that maintain the system's essential function while expanding its ability to learn and change. In the case of climate change, resilience is the capacity of human (including social and economic) and environmental systems to withstand the effects of climate change, namely weather events and their impacts. Climate change resilience initiatives are now being consciously implemented at all levels of government in developed countries. In developing countries, resilience more often takes the form of poor rural communities adjusting their lifestyles in response to climate change, rather than concerted, organized efforts to build resilience. It is important, therefore, for governments, aid organizations, and researchers to understand how developing communities respond to climate change and how their efforts can be improved within a framework of resilience thinking.

This review explores the definition of resilience and, more specifically, community resilience and its components, then presents four case studies of community response to extreme weather events to illustrate community resilience in action. This review is intended to provide context for and inform more detailed exploration of community resilience in integrated programming (specifically, programming designed to improve health, environment and population (PHE) outcomes). The review is also intended to capture references to population dynamics and family planning in the literature on community resilience, but is not intended as a definitive guide to the links between community resilience and health or family planning. 


\section{Methodology}

This review primarily compiled papers from academic, peer-reviewed journals, most of which were found through Google Scholar. Papers and reports published by governmental and intergovernmental agencies, as well as by NGOs, nonprofits, and other private organizations, were also used, along with selected online chapters from several books. Interviews with two persons working on joint conservation-and-humanitarian projects were also conducted. 


\section{Defining Resilience}

The term "resilience" has been popular in multiple disciplines for several decades, and there are thousands of definitions. It is now commonly used within the field of climate change and disaster risk management, with definitions that include the following:

"The ability of a social or ecological system to absorb disturbances while retaining the same basic structure and ways of functioning, the capacity for self-organisation, and the capacity to adapt to stress and change." (IPCC 2014)

"The capacity of a social-ecological system to absorb or withstand perturbations and other stressors such that the system remains within the same regime, essentially maintaining its structure and functions. It describes the degree to which the system is capable of self-organization, learning and adaptation.” (Resilience Alliance n.d.)

"The ability of a system, community, or society exposed to hazards to resist, absorb, accommodate to, and recover from the effects of a hazard in a timely and efficient manner, including through the preservation and restoration of its essential basic structures and functions." (UNISDR 2009)

In 1973, the ecologist C.S. Holling published a paper on ecological resilience, the ability of systems to absorb change and still maintain the same relationships between populations and state variables; Holling maintained that ecological systems seek equilibrium (and that this equilibrium is dynamic rather than static) after disruption. The Holling paper led to the use of resilience in sociology and in human geography, as in "resilient communities" (Alexander 2013).

The term resilience is often used in conjunction with other terms, such as adaptation and transformation. Across the literature, these terms switch meaning and function. Thus, sometimes resilience is considered a goal and sometimes a means to an end, sometimes a quality and sometimes a process or a state, sometimes a framework and sometimes a component within a framework. Other nuances and disagreements exist across the many definitions of resilience, including whether resilience is actually a positive or negative trait for a system to have; it should be noted that most modern literature, especially in disaster risk reduction, considers it positive. Resilience can be distinguished from adaptation by considering resilience a trait - the ability to bounce back from adversity - while adaptation can be considered the actions taken to react to shocks.

A key concept in discussions of resilience is the idea that systems achieve resilience through a simultaneous combination of maintaining and changing (though the extent of a system's needed maintenance or change is often disputed). There is a distinction drawn between engineering resilience - where a system returns to its exact initial condition following a change - and ecological resilience - where a system must change within limits to maintain its essential function (Cork 2010). The latter is the basis for the modern discussion on resilience: that resilient systems change in order to emerge from challenges even stronger than they were before.

Much of the discussion on resilience is theoretical, but some literature offers concrete examples of what resilience looks like in different systems. In social systems, trust-based social networks between friends and family, community organization members, and citizens and institutions help build resilience (Aldrich \& Meyers 2014). Resilient ecological systems contain a diversity of flora and fauna that can adapt to environmental changes (Gunderson 2000). In social-ecological systems, resilience-building practices include adaptive governance, ecosystem management, and disaster risk management. 
There is obviously great overlap among these different kinds of systems. This overlap is shown nowhere better than in communities, where social, ecological, economic, political, cultural, organizational, and individual psychological systems are all present and highly intertwined. Community resilience, especially within the context of climate change, is an entire discussion unto itself within literature, and is the focus of the rest of this review. 


\section{Community Resilience}

A community is a grouping of multiple natural and human systems, making the term "community resilience" a broad one. As with resilience, there are many definitions of community resilience, but they generally involve communities changing and adapting in the face of stresses (particularly climate stresses) in order to recover and retain essential function-in short, communities exercising general resilience. Among the definitions of community resilience are the following:

"The collective ability of a neighborhood or geographically defined area to deal with stressors and efficiently resume the rhythms of daily life through cooperation following shocks." (Aldrich \& Meyer 2014)

"The ability of communities to cope and adapt in the context of challenge and adversity in ways that promote the successful achievement of desired community results." (Mancini \& Bowen 2009)

"The capability to anticipate risk, limit impact, and bounce back rapidly through survival, adaptability, evolution, and growth in the face of turbulent change." (Community and Regional Resilience Institute 2013)

"The sustained ability of communities to withstand and recover--in both the short and long terms-from adversity." (National Biodefense Science Board 2014)

"A process linking a set of networked adaptive capacities to a positive trajectory of functioning and adaptation in constituent populations after a disturbance." (Norris et al. 2008)

Scholarship on community resilience programming most often focuses on poor or developing communities, as they are most vulnerable to risks (climate-related or otherwise) due to socioeconomic instability.

The most important force tying communities together and boosting community resilience is social capital, or "the aggregate of resources that arise from reciprocal social relationships in formal and informal networks, fueling community's ability to achieve desired results through collective action” (Mancini \& Bowen 2009). Social capital allows for social organization, or the process by which communities achieve their desired results. There are three main types of social capital: bonding, bridging, and linking (Aldrich \& Meyer 2014). Bonding capital describes the social networks between emotionally close community members, such as friends and relatives. Bridging capital describes the social networks between less close community members, often created through community activities and organizations. And linking capital describes the networks between regular citizens and those in power. Social capital is strengthened by trust built on a community's shared values and social norms.

In the case of dangerous weather events, people tied together through networks of bonding capital are first responders, ensuring that their friends and family members are safe. Bonding capital also helps with immediate recovery, as community members lend each other support and supplies (Aldrich \& Meyer 2014). Bridging and linking capital are better for long-term recovery, where social organization leads to community-wide initiatives in resilience-building and future disaster risk prevention, often through collaboration with local government, the formation of organizations, and the sharing of knowledge.

Another main characteristic of resilient communities is healthy populations and individuals. Healthy individuals are more able to physically withstand events like natural disaster and emotionally cope with the trauma that 
accompanies any sort of major disturbance. If a community is mostly comprised of healthy individuals, then the entire community is more resilient, and less healthy individuals can rely on healthier individuals for physical and emotional support. The National Health Security Strategy stated in 2009 that communities can build their resilience "by implementing policies and practices to ensure the conditions under which people can be healthy, by assuring access to medical care, building social cohesion, supporting healthy behaviors, and creating a culture of preparedness in which bystander response is not the exception but the norm" (US Department of Health and Human Services 2009: i). This statement illustrates the importance of health for both short-term disaster response and long-term recovery.

Health improves community resilience not only following major shocks, but also in people's everyday lives: healthy individuals can engage in productive labor and innovation and have more resources, including time and energy, to help others in their community, which promotes stronger community relationships. Community health is therefore critical for building economic and social resilience, as well as social capital (National Biodefense Science Board 2014). This accumulation of social, as well as economic and environmental, capital eventually lends itself to disturbance response.

In fact, health is so important to a community's resilience that it has earned its own subcategory of community resilience: community health resilience. According to the Community Health Resilience Initiative of the US Department of Homeland Security, community health resilience can be thought of as "the ability of a community to use its assets to strengthen public health and healthcare systems and to improve the community's

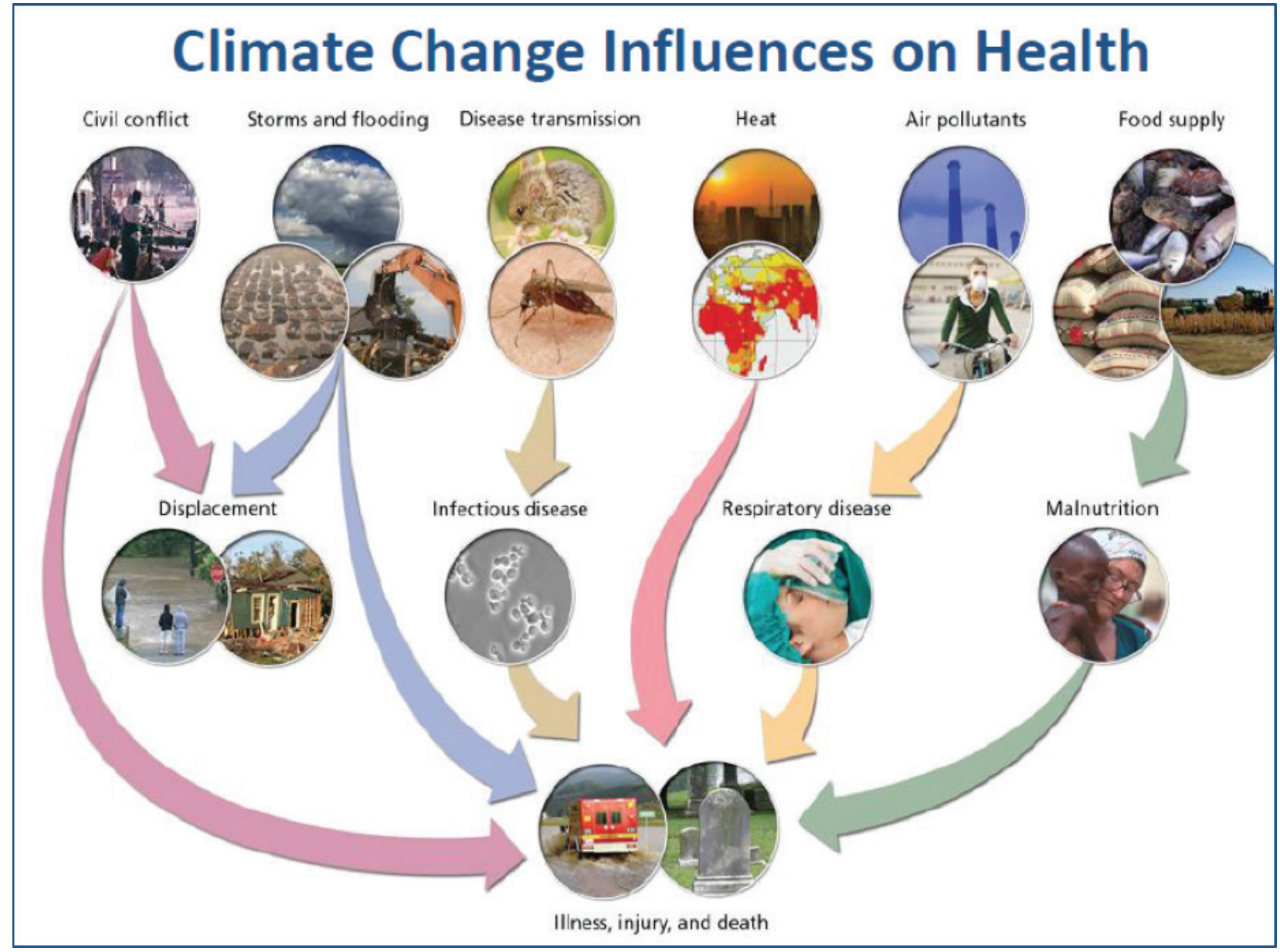

Source: Stiefel, 2016 
physical, behavioral, and social health, to withstand, adapt to, and recover from adversity" (Community Health Resilience Initiative n.d.). This definition emphasizes again the importance of health at an individual as well as community level, from both physical and emotional perspectives. Thus, a healthy community promotes individual health through informal and public health care systems, well-being through interpersonal systems like faith groups and social services, and social connectedness (National Biodefense Science Board 2014).

Other characteristics of resilient communities, specifically in the context of social-ecological systems, climate change, and extreme weather events, have been identified as socioeconomic and livelihood diversification; equity; flexibility and innovation in private sector and government institutions; reliance on past experience and indigenous and traditional knowledge; resource management; science, research, development, and technological innovations; education and training; infrastructure; strong fiscal sector; warning systems, emergency and evacuation plans, public awareness campaigns promoting risk knowledge, and locally-developed response plans; immediate response to a weather event and recovery after damage; participation by community at every level of mitigation, with the community taking charge; social values and structure; learning by doing; use of hard and soft technology; cross-sector adaptation; and access to aid, funding, and insurance from aid organizations, private businesses, and government (UCAR 2010; Norris et al. 2008; Kurniawan et al. n.d.; Haile 2005; UNFCCC 2007; Schaar 2014; Mayunga 2007; Blankespoor et al. 2010; Adger et al. 2003; Keim 2008). To be resilient, a community would ideally have all these characteristics; in reality, most communities will not have all of them. Among them, the most common characteristics are access to aid organizations, livelihood diversification, and reliance on social capital.

To illustrate the concept of community resilience and the different forms it can take, the next section provides case examples of how specific communities in Ethiopia, Mozambique, the Philippines, and Indonesia have responded to weather events. 


\section{Community Response to Weather Events}

To understand what community resilience looks like in real-life situations, this section explores four case studies of community response to climate events and how community resilience was expressed in those responses: drought in Ethiopia, flood in Mozambique, cyclone in the Philippines, and forest fire in Indonesia. These scenarios focus on vulnerable communities, namely communities that are mostly indigenous, rural, pastoral and/or agricultural, and poor. These cases are not intended to be representative of all examples of community resilience or of programmatic responses to adverse weather events. The weather events faced by these communities are the result of changes in climate rather than community actions, except for the Indonesia case study, in which climate change plays a role but is linked with human action.

Each case study examines multiple communities and multiple weather events in each country, rather than a single community or weather-related event. Though responses varied across the different communities in each country, the commonalities illustrate the overall capacities and priorities of those communities, and how they differed from communities in other countries. Each case study includes a brief discussion of the country's national climate change policy and/or disaster risk management approach, to understand how community resilience and response can be influenced by higher-level processes.

These case studies focus mainly on household responses, or how households "cope" with weather events, since the literature focused on household response as the basis of overall community response. Coping mechanisms, which can be positive or negative, are not synonymous with resilience, a decidedly positive characteristic of a community. Rather, coping mechanisms are considered simply as forms of response-in these cases, the actions taken by households or communities in advance of or in response to climate events and other disturbances. How households and communities respond, or cope, gives insight into resilience. 


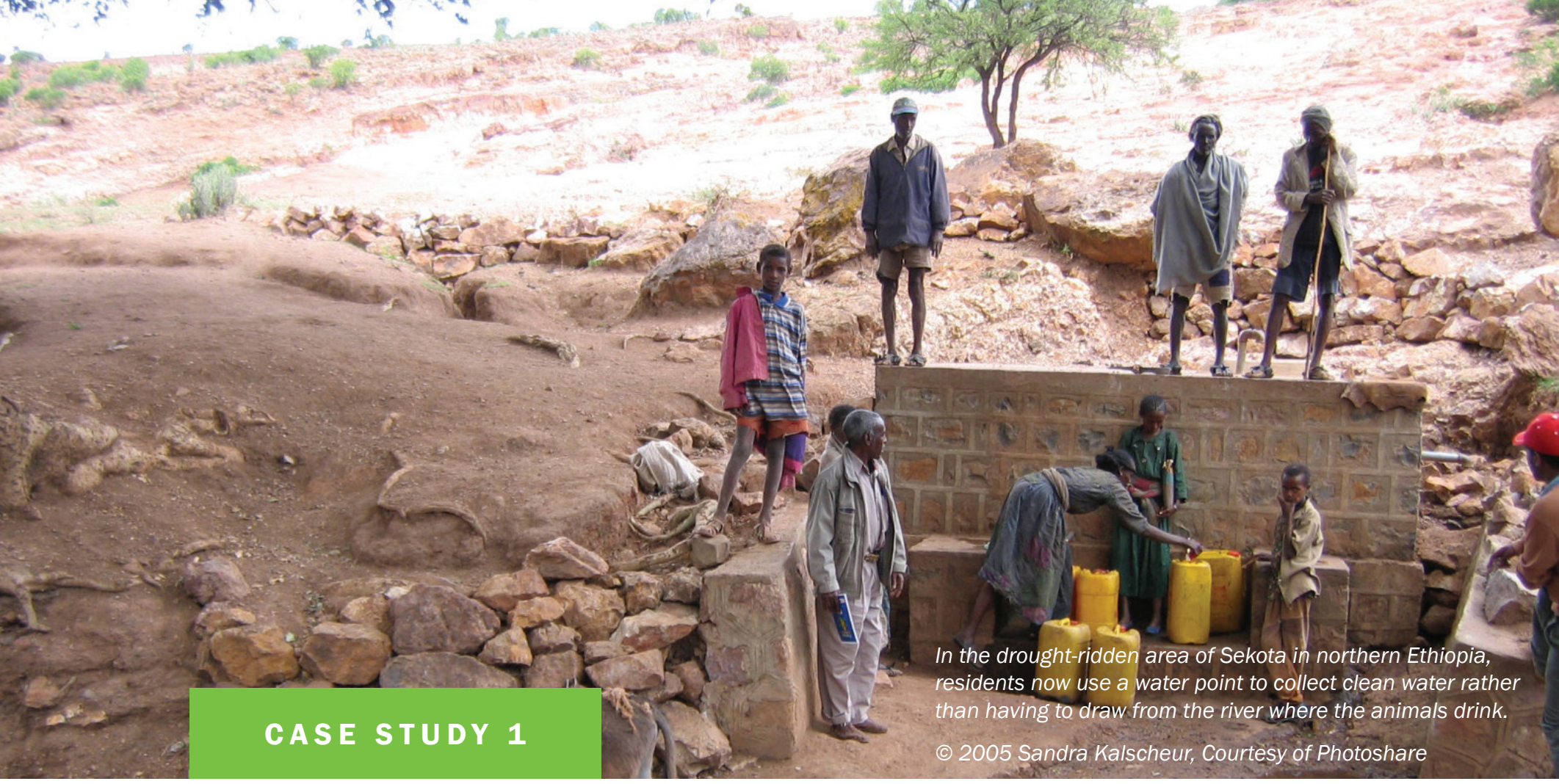

\section{Drought in Ethiopia}

An arid country to begin with, Ethiopia has suffered the effects of rising global temperatures due to climate change over the last 50 years. Between 1960 and 2006, Ethiopia's mean annual temperature increased by $1.3^{\circ}$ Celsius, and though its average national rainfall trends have remained constant, certain seasonal and annual rains have greatly declined (Regassa, Givey, \& Castillo 2010). These trends have led to repeated droughts and in turn repeated famines, including most recently a severe drought in 2014-2015, leaving over 10 million people in need of aid and considered to be Ethiopia's worst drought to date (Schemm 2016). The effects of drought in Ethiopia are exacerbated by its low adaptive capacity due to poverty $-77.5 \%$ of the population lives in poverty, $46 \%$ in extreme poverty (Regassa, Givey, \& Castillo 2010). Furthermore, 85\% of the population depends on agriculture to make a living, and there are an estimated 10 million pastoralists in Ethiopia (Birhanu, Berhanu, \& Ambelu 2015). With smallholders and pastoralists whose land-intensive professions are greatly threatened by the variability in temperature and rainfall, rural communities and households have been forced to adjust their lifestyles to preserve their incomes and lives. Responses come primarily from community members themselves, with little help from government or NGOs. The following description of these coping mechanisms comes from studies conducted in Borana, Jijiga, Tigray, the Nile Basin, Oromia, and the Southern Nations, Nationalities and Peoples' Region (SNNPR), and unspecified locations.

The top priority of all family members during drought is to earn and save money. In order to increase their savings, households limit expenditures and sell their productive assets (Birhanu, Berhanu, \& Ambelu 2015; Frankenberger 2015; Mengistu 2011; Kidanu, Rovin, \& Hardee 2009). They may also borrow money from banks, farmer associations, credit associations, and microfinanciers (Bryan, Deressa, Gbetibouo, \& Ringler 2009; Frankenberger 2015). One of the most common and most negative coping strategies used by households is to reduce their food consumption, limiting both the number of meals that family members eat per day and the amount of food per meal (Frankenberger 2015). No longer able to produce their own food, and unwilling to spend money on food at the market, they may consume mostly wild food (Pantuliano \& Wekesda 2008; Birhanu, Berhanu, \& Ambelu 2015). Children are often pulled out of school to help at home, though sometimes 


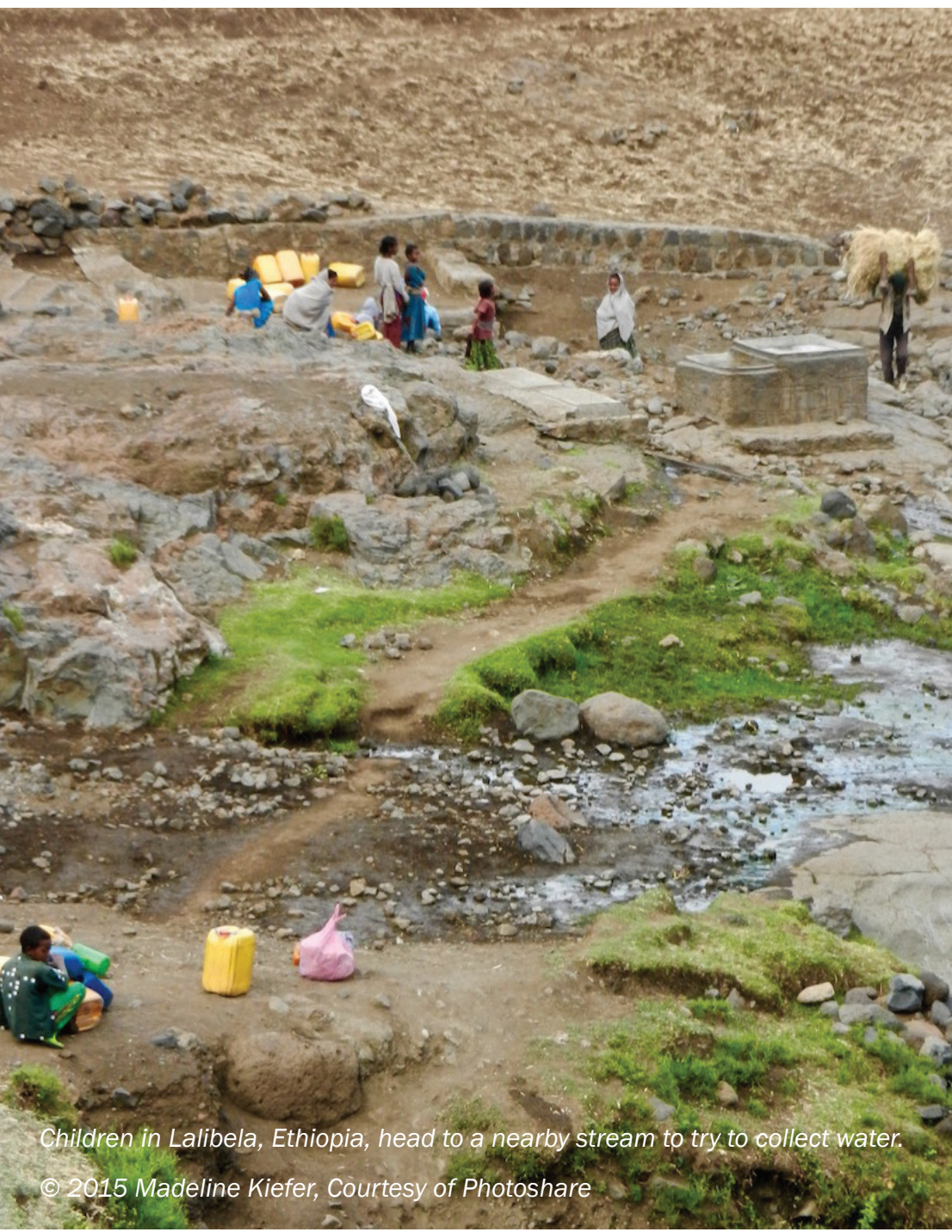

households try to put at least one child through school so that the child will gain the skills to find paid employment in the future (Frankenberger 2015; Pantuliano \& Wekesda 2008). Women are expected to diversify their income activities just like men (Frankenberger 2015; Pantuliano \& Wekesda 2008).

Indeed, income diversification is a universal coping strategy for Ethiopian households and is achieved through multiple means. Petty trade is common (Pantuliano \& Wekesda 2008). Households may harvest trees to produce charcoal and firewood, which they then sell at nearby markets (Birhanu et al. 2015; Mengitsu 2011; Kidanu et al. 2009). Sometimes they invest their assets outside the community; for example, they may build houses in nearby towns to get income from rent (Birhanu et al. 2015). Some people, most commonly men, migrate to towns to find jobs - such as sharecropping, mining, and construction - and send money back to their families (Birhanu et al. 2015; Bryan et al. 2009; Frankenberger 2015; Kidanu et al. 2009). This response-migration - has a long history in Ethiopia and is considered normal (Ezra \& Kiros 2001). It is one of the most common responses to drought, and interviews with community members after drought show that they consider it one of the most helpful responses as well (Mengitsu 2011).

For pastoralists, responding to drought is centered around what to do with livestock, and migration is important in this issue as well. Mobility is key; pastoralists will often move their livestock temporarily in search of water and pasture, though at other times entire families may move with the livestock to find permanent water sources (Birhanu et al. 2015; Frankenberger 2015). Clan leaders help coordinate these efforts: they send scouts in search of grazing land and negotiate with other clans for shared grazing land (Birhanu et al. 2015). Pastoralists save up fodder to feed their herds during drought, and they collect fodder from the wild to save money. Households also often sell their livestock when they anticipate a drought, or they slaughter their emaciated animals to sell during times of drought. Some buy animal insurance, acquire or breed drought-resistant cattle, diversify their herds, and keep larger herds to buffer the effects of drought. Some pastoralists even transition to agro-pastoral lifestyles as means of economic diversification.

Agriculturalists and agro-pastoralists have their own ways of responding to the detriment of drought. They develop irrigation systems and use soil and water conservation practices like terracing (Birhanu et al. 2015; Frankenberger 2015; Mengitsu 2011). To prepare for drought, they change their planting dates and diversify 
their crops, planting early-maturing and drought-resistant crop varieties (Bryan et al. 2009). During drought, they sell their crops for money or use them for food.

Traditional knowledge is also a factor in drought response. Traditional medicines are used for treating crop and livestock diseases (Frankenberger 2015). Indigenous people use environmental indicators like the behavior of animals, wind, and sky, as well as cultural beliefs like God's role in managing the weather, to forecast weather conditions (Mengitsu 2011). People pray to God for help and support, and elders especially are expected to pray (Birhanu et al. 2015; Frankenberger 2015).

Another custom, and perhaps the most significant coping strategy of Ethiopian communities and households, is reliance on traditional community networks. Community members often turn to family members and friends for loans on money, food, and goods, and their needs are willingly met when possible. But the social network extends far beyond these close ties. Redistribution of resources within communities—termed "Dabere" in Borana-is an expected and often compulsory act in which all community members take part (Birhanu et al. 2015; Frankenberger 2015; Pantuliano \& Wekesa 2008). Assets and services - often livestock, food, water, milk, land, seeds, crops, medical care, childcare, and needed labor - are given to or shared with the most disadvantaged community members. Funds are raised for the ill and the elderly, for funerals and births. Though these systems of social capital deteriorate as droughts go on and resources are strained, they are a major force in holding communities together.

Access to health services was also mentioned in the literature as key to resilience, with health interventions having generally been provided by NGOs rather than the government (Birhanu et al. 2015; Frankenberger 2015; Pantuliano \& Wekesa 2008). This may be changing, as the country's health extension program is identified as one of several key interventions in Ethiopia's Vision for a Climate Resilient Green Economy (The Federal Democratic Republic of Ethiopia n.d.) Earlier, as part of the Humanitarian Reform Agenda, the UN rolled out the "cluster approach" in Ethiopia, which includes health as one of nine critical areas (Pantuliano \& Wekesa 2008). Writing about pastoralists coping with recurring drought in the Borana Zone, Birhanu et al. (2015) noted that the Borana linked human health and the health of their cattle, in addition to access to water, with having a better and fulfilled life. Birhanu et al. (2015) cited the need for responsive health services, family planning, and capacity building for district health leadership and management, among other interventions, to help communities cope. Kidanu et al. (2009) also found that, in the regions of Oromia and SNNPR, sub-urban and rural communities noted the importance of access to family planning, among other interventions, to build resilience.

Finally, local leadership also plays a role in how Ethiopian communities and households respond to drought. Clan leaders often oversee the redistribution of assets detailed above. In Borana, it was noted that clan leaders are not as effective at organizing a community during drought as in non-drought periods, in large part because they too are affected by the drought and do not have the time to support others (Frankenberger 2015). However, they still help oversee deals and moderate disagreements between community members, collect funds, organize farm work, hold discussions about managing community resources, and organize searches for livestock (Frankenberger 2015). In other locations, the local government works to provide for individual needs while helping the community as a whole. For example, food-for-work programs in Oromia, SNNPR, and Tigray, allow community members to work on activities such as building dams and irrigation systems and planting trees in return for food (Mengitsu 2011; Kidanu et al. 2009). Working as part of the national government response, local governments also distribute food and water, organize school feeding programs, and dig wells and construct irrigation systems. 
The government's response to disaster among pastoralists under the Disaster Prevention and Preparedness Agency, the Food Security Coordination Bureau, the Early Warning Department, and the National Disaster Prevention and Preparedness Fund (Pantuliano \& Wekesa, 2008) has been limited. However, Ethiopia was among the least developed states to develop a National Adaptation Program of Action (Federal Democratic Republic of Ethiopia 2007) and its Programme of Adaptation to Climate Change and (most recently) its Vision for a Climate Resilient Green Economy (Federal Democratic Republic of Ethiopia n.d.) both include a focus on building resilience and developing a green economy. 
members to other villages or urban areas to find work; in some areas, it is considered a rite of passage for young men to participate in migrant work to support their families.

The above strategies are used by Mozambican communities in preparation for and response to most types of natural disaster. But these communities also employ strategies meant specifically to deal with flooding. Infrastructure changes are especially prevalent. In both the Zambezi delta and Búzi case studies, houses are built in areas of higher elevation, and with upper floors, to prevent the houses being flooded (Artur and Hilhorst 2012; Matsimbe 2003). In the Zambezi, houses are constructed with grass and wood, materials whose destruction during a flood would not represent an investment loss; however, in Búzi, community members build houses from stronger materials that could hopefully withstand a flood. Other preventative measures including removing roofs from houses during the beginning of cyclones, planting bamboo around houses to protect them from the wind, and building small huts to protect livestock (Matsimbe 2003). On the agricultural side, farmers employ dual land-use systems: they plant their usual crops in irrigated lowlands, but in case these lowlands flood they also grow "insurance" crops in sandy soil at high elevation (Osbahr et al. 2008). Asset accumulation is organized in a similar fashion. Households often stock up on easily disposable assets, like small livestock, that they can afford to lose during flood. They avoid accumulating big items, like large animals and furniture, and instead invest in items that would be helpful and easily transportable during flood - items like canoes, fishing nets, radios, poultry, and silverware and plateware (Artur \& Hilhorst 2012). Canoes and other small boats are especially important as means of evacuation during critical floods.

On this note, communities often have pre-planned means of warning and evacuation in case of flood. Traditional knowledge of year-round weather patterns and environmental indicators are used to prepare for and predict floods (Matsimbe 2003). However, more organized methods of warning also exist, though they are not always effective. In Búzi during the 2000-2001 flood, administrative authorities were warned of rising river water levels 48 hours in advance, and they in turn warned the communities surrounding their headquarters. Warnings may be posted in public places with different colored flags signifying the urgency of the flood (Matsimbe 2003). In terms of actual evacuation, people often prefer not to evacuate, fearing that they will lose their assets and property (Artur \& Hilhorst 2012). In the Zambezi case study, when people were notified of the flood, they first moved from the lowlands to their house on higher grounds, then to their granaries built on poles, then to nearby hills and sanctuaries; only when flood levels threatened these places did they agree to evacuate (Artur \& Hilhorst 2012). Once evacuation begins, emergency response is taken first through informal networks, with neighbors, friends, and family aiding one another (Matsimbe 2003). Households use their own boats to flee; if certain community members do not own a boat, other households will rescue them. Though the Mozambican government has responded well to past floods by issuing warnings, ordering evacuations, and organizing rescue missions (UN Country Team in Mozambique 2015), communities prefer to use their own resources to save themselves, though they do agree to evacuate to the temporary and permanent resettlement areas provided by the government (Artur \& Hilhorst 2012).

This preference for informal community resources rather than formal governmental ones reveals another, and perhaps the most important, coping strategy that Mozambican communities rely on: social capital and networks. There exists the usual support, loans, and sharing of resources among family and friends. But there is also a larger "gift system" connecting all community members, as in Ethiopian communities, though the Mozambican system focuses more on reciprocity than redistribution (Osbahr et al. 2008). Community members exchange supplies and especially labor. Through individual and group arrangements, people engage in activities such as rebuilding others' houses after floods, watching their livestock, and working their land; the same is done in return (Matsimbe 2003; Osbahr et al. 2008). The women in the Gaza Province have their own exchange network called Matsoni, which involves planting a dryland crop that can support the community in case of flood (Osbahr et al. 2008). 
A community's social ties with other villages are also important, as neighboring communities often provide each other with support (Osbahr et al. 2008). Intra-community and intercommunity ties are strengthened through marriages, gifts, festivities, and other arrangements (Artur \& Hilhorst 2012).

Mozambican communities also have access to many formal support systems. For example, farmers' associations allow farmers to share their knowledge and train others in activities like agro-forestry and using new crop varieties and technologies (Osbahr et al. 2008). And beyond issuing warnings and organizing evacuation, local governments also collaborate very often with NGOs in organizing meetings and workshops for community members on resource management and disaster preparedness (Matsimbe 2003).

Some attention to health issues related to flooding and responses have appeared in the literature on resilience and coping with flooding in Mozambique (USAID 2012). In an assessment of the role of local institutions in reducing the vulnerability of at-risk communities in Central Mozambique in response to flooding in 2000, Matsimbe (2003) noted that riverine communities had increased health risk due to the emergence of waterborne diseases. In 2000, the government appointed a national coordinating mechanism chaired by the National Institute of Disaster Management (INGC), with flood committees established at provincial and district levels. The INGC worked with the UN, donors, NGOs, and religious organizations to evaluate the needs of affected communities and to provide disaster relief, including medical assistance.

Reconstruction of health facilities is a longer-term objective in response to flooding. Response to the 2015 flood, also coordinated by the INGC, followed a similar pattern, with initial emergency assistance through a cluster approach response, with partners providing basic health care services in affected areas (UN Country Team in Mozambique 2015). Appeals for support for flooding in 2017 have also included health care and water and sanitation, particularly in light of a cholera outbreak (Apa News 2017).

Local government responses are facilitated by Mozambique's relatively strong national climate change and disaster risk reduction policies. The literature revealed many cases of the Mozambican government stepping in to help communities after floods and other disasters, providing evacuation help, shelter and resettlement, and food and supplies to disaster victims. In addition to participating in many international adaptation programs, Mozambique has a 2007 National Action Programme of Adaptation that includes a Clean Development Mechanism and also a 2011 National Action Plan for Reducing

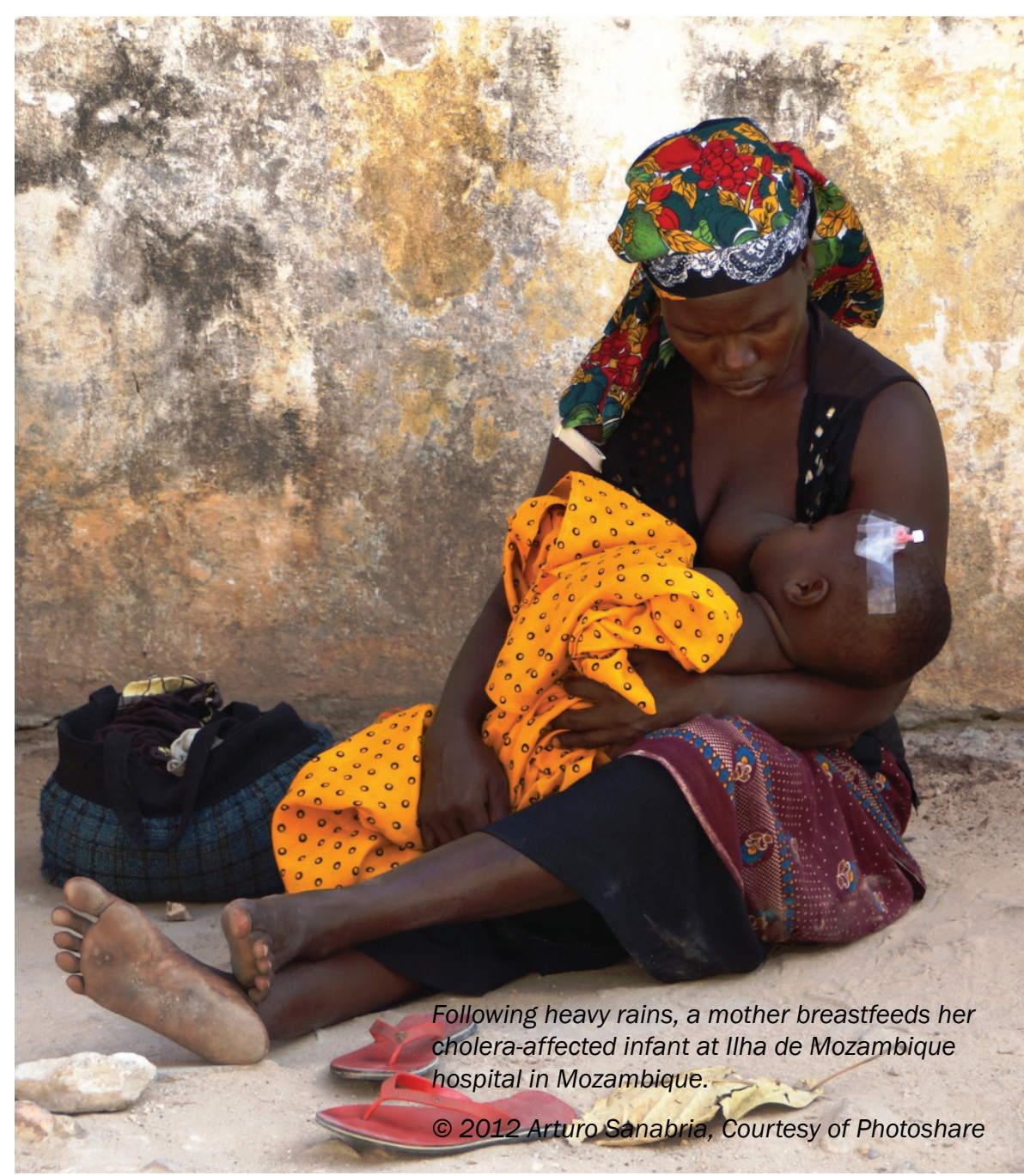


Poverty (USAID 2012; Artur \& Hilhorst 2012). Though a lot of disaster efforts are organized by the National Institute for Disaster Management, there is a strong emphasis placed on decentralizing disaster risk management to local administrative offices for more effective response. 


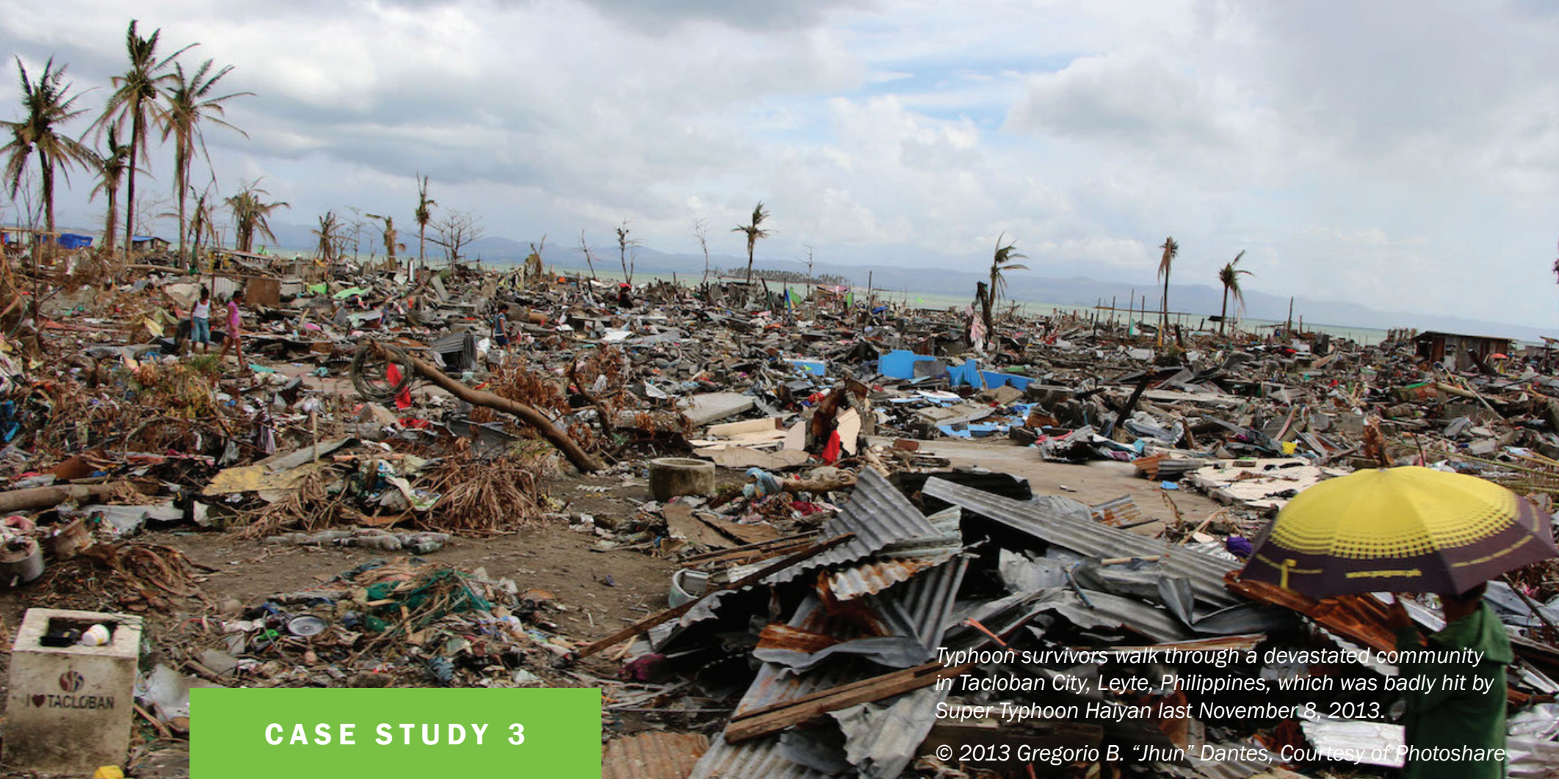

\section{Cyclone in the Philippines}

The Global Climate Risk Index 2015 ranks the Philippines as the most climate change-affected country in the world (EcoWatch 2016). This classification is in great part due to the Philippines' location and geography; it is an archipelago located in the Pacific Ocean, making it particularly vulnerable to sea level rise and tropical storms. Accordingly, cyclones are the most frequently occurring natural disaster in the Philippines; the country experiences approximately 20 tropical storms per year (Sawada et al. 2009). With a Human Development Index ranking of 115th out of 188 countries and around 15\% of its population living in or near poverty (UNDP 2015b), the Philippines is a more developed nation than Ethiopia or Mozambique, allowing for more developed, wealthy and therefore more climate-resilient communities, as well as more substantial government aid to communities affected by tropical storms. However, a 15\% poverty rate-some sources place that figure closer to $20 \%$ - is still substantial and poverty is still a major issue in the country, making Philippine communities climate-vulnerable. In addition, about half of the population lives in rural areas and relies on agriculture and fishing for sustenance and income, a lifestyle that is greatly threatened by the prevalence of cyclones, and people are therefore forced to take preventative, preparatory, and reactionary measures to cope with the effects of tropical storms. People in wealthy villages and urban slums are also greatly affected by tropical storms, and they practice their own sets of coping mechanisms. This section's discussion of these coping strategies is drawn from case studies of Typhoon Milenyo in East Laguna village, a Red Cross Project in the Tigbao district, along with a compilation of studies on flooding in Metro Manila and Zoleta-Nantes, typhoon Milenya, typhoons Ondoy and Pepeng, floods caused by Ondoy, typhoon Sendong, typhoon Pablo, among others.

Philippine communities use a large, varied, and innovative set of coping strategies that are often highly organized. This coordination is afforded in great part by the extensive help that these communities receive from NGOs and government. However, they share many of the coping strategies discussed in the case studies in Ethiopia and Mozambique. 


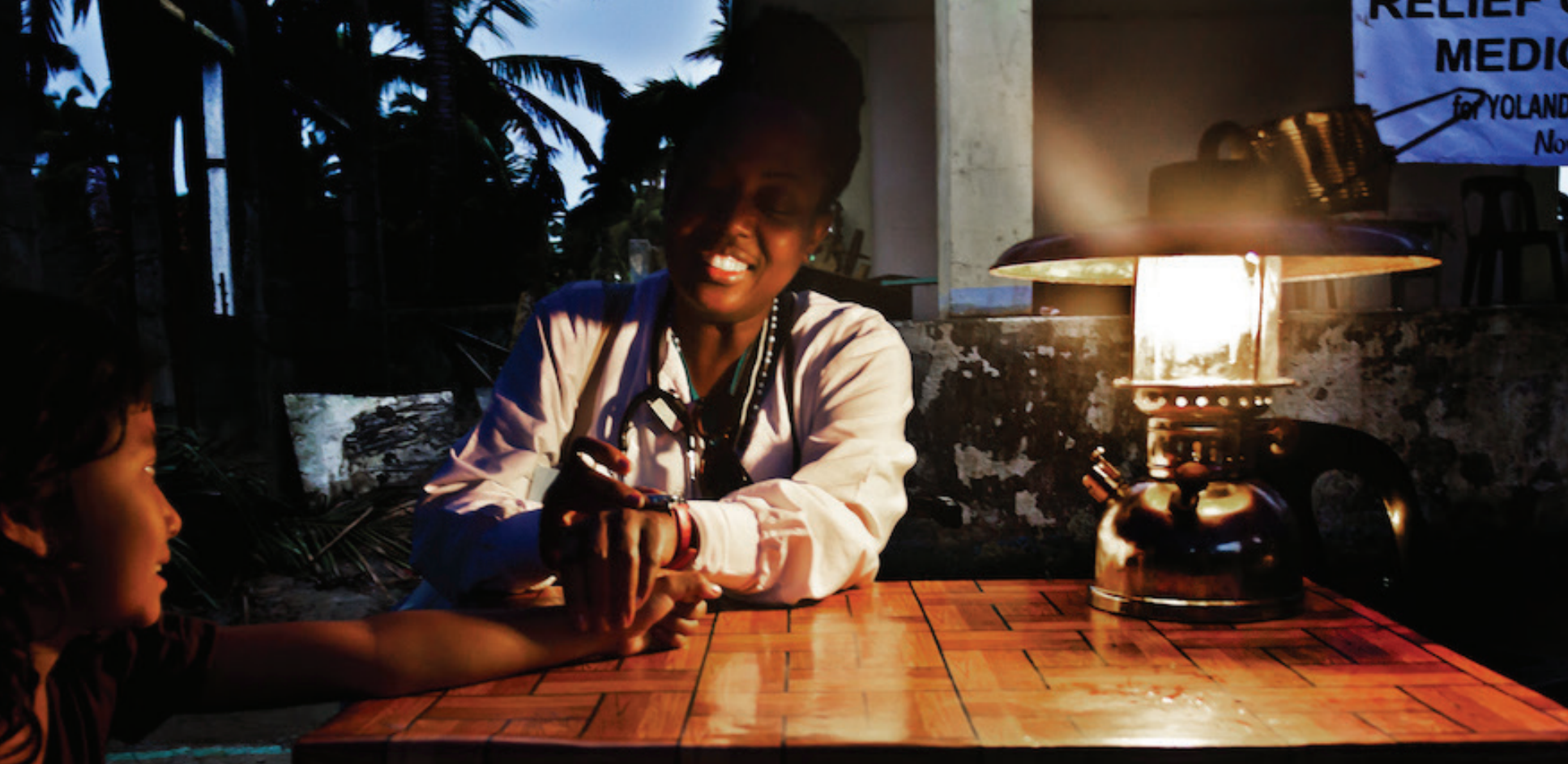

A volunteer health worker takes the pulse of a child in Samar, Leyte, Phililppines, during aid efforts following Typhoon Haiyan.

(C) 2013 KaiAvila, Courtesy of Photoshare

For example, Philippine households reduce their food consumption and expenditures, sell their household and agricultural assets, and migrate in response to cyclones (Allen 2003; Israel \& Briones 2014; Sawada et al. 2009; Tibig 2003; Uy et al. 2011). In addition, as with the other case studies, using social networks is a fundamental coping strategy in Philippine communities, as households seek emotional and financial support from friends and relatives (Israel \& Briones 2014). Friends and community members may also provide loans, and food, to one another following a storm (Israel \& Briones 2014; Sawada et al. 2009; Uy et al. 2011). A few studies show that households first ensure that their families are moved to safety when a storm hits, but they also share emergency evacuation places with friends and community members (Israel \& Briones, 2014).

Philippine communities place added emphasis on obtaining loans from banks, relatives, friends, neighbors, moneylenders, pawnshops, and stores, as well as remittances from migrant family members working abroad (Israel and Briones 2014; Sawada et al. 2009). They also make sure to stockpile food and emergency supplies in case of evacuation, and many households own boats for easy mobility during floods (Israel \& Briones 2014; Tibig 2003).

As for livelihoods, households regularly engage in a wide variety of livelihood activities because they know this will reduce their financial risks following the occurrence of tropical storms. The general livelihood activities are agriculture, mainly rice farming, and fishing. But people also have jobs in transportation, carpentry, construction, electrical work, and factory work (Sawada et al. 2009). Migration to urban centers or abroad to find work and send money back to one's family is also not uncommon (Allen 2003).

Constructing storm-resistant infrastructure is one of the main actions that communities take in preparation for cyclones. People build flood- and typhoon-resilient houses or reinforce their houses to make them more 
resilient. They build houses on stilts or use other methods of elevating the level of the first floor to prevent flooding, and they situate houses in areas where they will be protected from strong winds (Israel \& Briones 2014; Tibig 2003; Uy et al. 2011). They also construct seawalls, embankments, and other means of protection against flooding, especially for crops (Allen 2003; Tibig 2003). The planting of mangroves along the coastline is a wellknown method that Philippine communities use to prevent erosion. They also plant trees above settlements, around farms, and along riverbanks and steep inclines to protect against floods and winds (Tibig 2003). Many communities use ditches and canals to divert rainwater and streams away from agricultural land to prevent the destruction of crops, and other structures are used for collecting rainwater (Allen 2003; Tibig 2003).

Other agricultural strategies to protect against the destruction caused by tropical storms include pruning and cropping trees to lessen their weight, multicropping and intercropping, and crop diversification to include drought-resistant and root crops (Allen 2003; Tibig 2003; Uy et al. 2011). They also try to locate some crops on elevated land and quickly harvest ready crops before a typhoon hits (Tibig 2003).

As in Ethiopia and Mozambique, there is less mention of health in response to cyclones than to other coping mechanisms. For example, Tibig (2003) does not mention health among local coping strategies and technologies for adaptation in the Philippines. Israel and Briones (2014) do note that poorer households are disadvantaged relative to better off households in accessing healthcare, among other services, in times of disaster, and they also note the dearth of data available to more fully examine health-seeking behavior in times of disaster. Analyzing data from the Family Income and Expenditure Survey (FIES) and Demographic and Health Survey (DHS), along with a panel dataset of province-level typhoon incidence, Antilla-Hughes and Hsiang (2013) were able to show that in the year following exposure to a typhoon, an average Filipino household's income was $6.6 \%$ lower, with a $7.1 \%$ reduction in expenditures, including a $14.3 \%$ reduction in expenditures on health. To augment national response through the country's medical infrastructure, emergency response from donors includes health-related assistance, notably medical and sanitation supplies and efforts to vaccinate for tetanus to combat infection (Christiansen 2013). The UN's cluster approach, including health-related assistance coordinated through WHO, has also been applied during cyclones in the Philippines (Tran 2014).

Indigenous communities use their own set of responses in addition to all of the above coping strategies. They practice hazard mapping, whereby they observe the geography of potential settlement sites and decide on areas where flooding and typhoon winds can be avoided (Tibig 2003). They use indigenous knowledge, such as the behavior of animals and the appearance of clouds, to forecast weather events. They also have formal early warning systems, where they use horns, drums, and other means to notify the community of an approaching storm (Tibig 2003). People look to tribal leadership to coordinate these efforts, as well as to provide support and aid to the community during weather events.

Non-indigenous and urban communities rely heavily on local government, which coordinates many disaster management efforts. Local governments often have the technology to detect approaching storms, and they have early warning systems in place for notifying their communities (Israel \& Briones 2014). They may open village meeting halls or other temporary shelters during storms (Sawada et al. 2009). Post-cyclone, local governments provide food bags and cash to the most severely affected households, as well as iron sheets for households whose roofs were lost during the cyclone. They also engage in strict price and supply monitoring to avoid price hikes (Sawada et al. 2009). Some local administrations work with other villages and appoint counselors to form sectoral committees on disaster coordination (Allen 2003). Perhaps most importantly, local governments coordinate projects with NGOs to provide relief to storm-affected communities. 
Indeed, NGOs play a huge role in helping Philippine communities. They provide food and supplies to affected households and help fund and coordinate infrastructure projects to protect against future storms (Allen 2003).

The ability of local governments to provide for their communities is afforded by the Philippines' extensive national disaster risk management and climate change policy. The Philippine Disaster Risk Reduction and Management Act, as well as the Climate Change Act, focus on integrating disaster risk reduction and climate change mitigation into national policies and programs (Israel \& Briones 2014). These efforts are executed through the country's National Adaptation Plan, National Disaster Risk Reduction and Management Council, and Climate Change Commission. 
undertake small-scale, non-mechanized forest logging projects for temporary employment (Wunder et al. 2008). However, in 1970 the Indonesian government centralized control of the forests and allocated land concessions to large corporations exclusively; all logging had to be mechanized, and communities received few benefits from corporate logging projects. In 1998, district authorities were reauthorized to issue small-scale logging permits to individuals and communities, but local timber brokers transferred the rights of communities to harvest timber to logging companies. As a result, the government revoked the ability of district authorities to issue permits in 2000, and it banned all forms of community permits in 2002 (Wunder et al. 2008).

These political maneuvers have led to the environmental degradation of forests (creating forest fires) and the economic detriment of communities (making them more vulnerable to the effects of forest fires). As part of their subsistence-agriculture lifestyles, communities have long used swidden (slash-and-burn) agriculture to clear land for growing crops; this creates a prime environment for forest fires, as farmers set the land on fire in order to clear it, often during the dry season. However, these practices are mostly small-scale. It is the introduction of large corporations and plantations that has led to widespread forest fires. A timber corporation that holds the timber concession for a (usually large) piece of land will come in, cut all the timber, and then sell the concession to a plantation corporation (usually for palm oil). The palm oil corporation will then come in, drain the land for peat, and then set fire to the land to clear it for palm oil production (Kois 2016).

Community members, pushed by poor health and poverty to seek better income sources, play a part in these activities. They engage in illegal logging and sell trees to timber companies, or they work directly for timber and plantation companies to help clear the land with slash-and-burn (Health in Harmony 2016; Kois 2016; World Bank 2015). As a result of all these practices, in one district of West Kalimantan, deforestation averaged 2.9\% per year from 1989 to 2008, and palm oil corporations have come to control over 13\% of community-managed lands, with timber corporations controlling even more (Carlson et al. 2012). In 2015 alone, the burning of millions of hectares of forest land caused over $\$ 16$ billion in damage (World Bank 2015). These activities, as well as a hotter and drier climate caused by climate change, contribute to the high prevalence of forest fire in Indonesia.

These practices only hurt the forests' surrounding communities. Forest fires caused by logging and plantation activities have become so common that a so-called "haze" of air pollution hovers over Indonesia, causing respiratory illness and other health problems for nearby communities (World Bank 2015). Meanwhile, the corporations take over (and the fires they cause destroy) land that communities use for agriculture, agroforestry, and other livelihood activities, causing people to lose their sources of income. They turn to logging companies for work, but this work only perpetuates their physical and financial problems. The corporations reap most of the benefits while the forest communities suffer, and the national government has done little to fix these problems.

ASRI seeks to address these issues through its work in Sukadana. In meetings between the organization and different communities, community members explained their reliance on illegal logging and identified the drivers of this activity as lack of access to healthcare and economic alternatives (Health in Harmony 2016). ASRI thusly takes a three-pronged approach to helping the villages surrounding the Gunung Palung National Park, combining conservation, healthcare, and livelihood improvement measures to help communities cope with the effects of deforestation and resulting forest fires.

These initiatives in conservation, healthcare, and livelihood improvement have been highly intertwined from the start. Soon after it began operating in Indonesia, ASRI established its clinic in Sukadana to provide healthcare at affordable rates for community members. The clinic takes non-cash payments like native handicrafts, as well 
as seedlings and organic manure to be used for reforestation and sustainable farming (Health in Harmony). The clinic also has a "green credit system," in which villagers who do not participate in illegal logging receive discounts of up to $70 \%$ off on healthcare services (Health in Harmony 2016). Weekly education on environmental conservation and hygiene practices is also provided. On the livelihood front, the Sukadana clinic (as well as a mobile clinic that travels to isolated villages) is run entirely by Indonesian staff, trained by Western medical professionals, thereby providing jobs for community members. A Community Hospital and Training Center is currently under construction and will provide training and yet more employment opportunities for villagers (Health in Harmony 2016).

Other livelihood initiatives include the Forest Guardians program, instituted in 2011. Through this program, thirty villagers and counting have been hired onto ASRI staff to monitor logging activity in their communities and to help loggers seek alternative livelihoods (Health in Harmony 2016; Kois 2016). The Sustainable Farming program allows for similar outreach, with ASRI staff training local farmers in sustainable agriculture methods, such as using local materials and organic methods and keeping plots of land rather than abandoning them after a few years (Health in Harmony 2016; Kois 2016). Female community members are also economically empowered through the Goats for Widows program; goats are provided to the communities' most disadvantaged households, often headed by widows, as a supplementary source of income for their families, as well as a source of goat manure for the Sustainable Farming program (Health in Harmony 2016; Kois 2016).

On the conservation front, in addition to training farmers in alternatives to slash-and-burn, ASRI hires villagers for its reforestation program, which seeks to regrow forest areas lost to fire and the activities of logging and plantation companies. ASRI has two reforestation sites: Laman Satong and Sedahan. The ASRI staff teaches community members how to prepare, plant, and care for seedlings and ensure that these sites and others grow (Health in Harmony 2016). Another program, ASRI Kids, educates hundreds of schoolchildren about the importance of protecting the rainforest, global diversity, tree planting and care, trash and proper disposal, basic hygiene, and sustainable wood foresting (Health in Harmony 2016; Kois 2016). In addition to educating children through these lessons and through field trips to the rainforest, reforestation sites, and sustainable farms, this program encourages children to bring their new knowledge back to their friends, family, and community (Kois 2016).

These initiatives in healthcare, livelihood improvement, and conservation help Indonesian communities prevent, prepare for, and cope with the effects of forest fires. Tying all of this together is social capital, both within the communities themselves and between the communities and ASRI. According to Ms. Kois, social networks based on Muslim values govern interactions in all the communities. People will help anyone in need, whether they be family members, community members, or even outsiders (Kois 2016). There is a strong culture of care and hospitality that helps communities respond to fires and other struggles. ASRI recognized the importance of social capital in these communities and sought to build that capital at the very start through "radical listening," or listening before acting (Health in Harmony 2016). In 2007, before deciding on its operation site or function, ASRI held over 1,500 hours of meetings with community members to understand their greatest struggles and hear what action they thought should be taken (Kois 2016). The organization then based its programs off the stated needs of the communities, receiving community input throughout the process and continuing to receive it today.

The social capital built between ASRI and the Kalimantan communities is what allowed for the response that the communities took during and after a forest fire consumed one of ASRI's reforestation sites (located very close to a village) in the summer of 2015. The reforestation manager, a village member hired by ASRI to live in a house near the reforestation site and monitor the activity there, first notified the village of the fire 
(Kois 2016). In response, community members worked with ASRI staff to ensure that everyone got to safety. Having developed a strong personal connection to the site, they also helped fight the fire, and there was a great community outpouring to restore the site afterward (Kois 2016). ASRI paid villagers to plant a tree buffer around the site, test the soil for dampness, and replant the site. According to Ms. Kois, it is healthcare, livelihood activities, and social capital that have made the West Kalimantan communities more resilient to deforestation and forest fires and that have allowed ASRI to be so successful (Kois 2016).

As stated previously, the Government of Indonesia does little for the kinds of communities that ASRI helps, in great part because it receives a profit from the plantation activities that destroy forest land. In fact, the government hopes to double palm oil production by 2020 (UNDP 2015c). Still, commitments have been made by the government to restore 2 million hectares of forest in the coming years (Porter 2016). Indonesia's broader policies regarding climate change and weather events include a National Adaptation Plan, as well as recent legislation regarding geothermal, meteorological, environmental protection and management, and energy law. The Ministry of Forestry sometimes plays a role in aiding communities affected by forest fires, but its efforts are limited (Kois 2016). 


\section{Conclusion}

This review summarizes the literature on resilience, community resilience, and responses to weather events from four countries, to provide context for and inform more detailed analyses of connections between resilience and integrated programming (specifically population, health, and environment). Following an overview of the concept of resilience, the review discusses community resilience in detail, including what constitutes a community, the main contexts of community resilience, social capital theory, and pragmatic examples of community resilience. The case studies highlight community responses to drought in Ethiopia, floods in Mozambique, cyclones in the Philippines, and forest fires in Indonesia, and how community resilience is expressed in those responses.

To illustrate community resilience in action, four country case studies describe how rural communities in developing countries respond to weather events, including their own household- and community-generated coping mechanisms and the help they receive from NGOs and local and national government. There were similarities across all four case studies in household response and coping strategies, including use of bonding, bridging and linking social capital and networks for assistance, borrowing, and reciprocity; migration; reduction in food consumption and expenses; new infrastructure; agricultural reform (specifically crop diversification); investment in loans, insurance schemes, and credit; sale of assets; diversification of livelihoods through alternatives like petty business; using indigenous knowledge to predict weather events; reliance on traditional community leaders; and cooperation with NGOs and local government. Attention to health - notably clean water for sanitation, infection control, and access to medicines and health services - also featured across the countries, although less consistently than other factors, and mostly as a response from NGOs. The need for family planning to build resilience was noted in Ethiopia.

Responses differed across the case studies, depending on the type of weather event to which the communities were responding, as well as the extent of government and NGO involvement and aid. For example, community response in Ethiopia came almost entirely from the community itself, with little to moderate help from government and NGOs. Mozambique's communities also had highly community-based responses, but unlike Ethiopian communities they had the added help of greater national government involvement. Communities in the Philippines relied heavily on aid organizations, but also on very active assistance from the government; both forms of aid are afforded by the Philippines' development status, which is more advanced than those of the other countries. Indonesia's community response was greatly intertwined with NGO and aid organization involvement, but there was almost no aid from the national government.

The case studies highlight the centrality of community-based solutions to responding to weather-related events, and also show how these responses are embedded within larger-scale national responses to climate change, composed of national policies and programs, international treaties, and multilateral and multi-organizational projects. These national efforts sometimes involve working directly with communities, and sometimes operate exclusively at federal levels.

The review and country case studies show that programming to strengthen community resilience in the face of adverse weather events should center around community networks and social capital and should support community-driven responses. Health is considered an important dimension of community resilience, but does not figure prominently in programming - at least in the four country case studies included in this review. Understanding this can help governments, NGOs and donors improve programming related to adverse weather events and intensify support for health, including reproductive health and family planning, as a mechanism to build community resilience. 


\section{References}

Adger, W. N., Huq, S., Brown, K., Conway, D., and Hulme, M. 2003. Adaptation to climate change in the developing world. Progress in development studies, 3(3), 179-195.

Aldrich, Daniel P. \& Meyer, Michelle A. 2014. Social Capital and Community Resilience. American Behavioral Scientist, 59.

Alexander, D. E. 2013. Resilience and disaster risk reduction: an etymological journey. Natural Hazards and Earth System Sciences, 13, 2707-2716.

Allen, K. 2003. Vulnerability reduction and the community-based approach. In: Natural disasters and development in a globalizing world, 170-182.

Antilla-Hughes and S. M. Shiang. 2013. Destruction, Investment, and Death: Economic and Human Losses Following Environmental Disaster. Columbia University, School of International and Public Affairs and Princeton University, Woodrow Wilson School of Public and International Affairs. http://cega.berkeley.edu/ assets/cega_events/49/Session_4E_Natural_Disasters.pdf

Apa News. 2017. “Cholera Outbreak Spreads in Flood-hit Mozambique.” Apa News. March 15. http:/ /apanews. net/en/news/cholera-outbreak-spreads-in-flood-hit-mozambique. Accessed May 25, 2017.

Artur, L., and Hilhorst, D. 2012. Everyday realities of climate change adaptation in Mozambique. Global Environmental Change 22.2: 529-536.

Bahadur, A., et al. 2015. The 3As: Tracking Resilience Across BRACED, 1-57. Building Resilience and Adaptation to Climate Extremes and Disasters.

Berkes, F., Colding, J., and Folke, C. (Eds.). 2008. Navigating social-ecological systems: building resilience for complexity and change $(2,7,14)$. Cambridge University Press.

Balzer, N., and Hess, U. 2010. Climate change and weather risk management: evidence from index-based insurance schemes in China and Ethiopia. United Nations World Food Programme.

Birhanu, Z., Berhanu, N., and Ambelu, A. 2015. Rapid Appraisal of Resilience to the Effects of Recurrent Droughts in Borana Zone, Southern Ethiopia.

Blankespoor, B., Dasgupta, S., Laplante, B., and Wheeler, D. 2010. The economics of adaptation to extreme weather events in developing countries. Center for Global Development Working Paper (199).

Bryan, E., Deressa, T. T., Gbetibouo, G. A., and Ringler, C. 2009. Adaptation to climate change in Ethiopia and South Africa: options and constraints. Environmental science \& policy, 12(4), 413-426.

Carlson, K. M., et al. 2012. Committed carbon emissions, deforestation, and community land conversion from oil palm plantation expansion in West Kalimantan, Indonesia. Proceedings of the National Academy of Sciences, 109(19), 7559-7564.

Christiansen, J. 2013. “Typhoon Creates Health Crisis in the Philippines.” http://www.cnn.com/2013/11/11/ health/typhoon-medical-crisis/

Community and Regional Resilience Institute. 2013. Definitions of Community Resilience: An Analysis, 1-14.

Community Health Resilience Initiative. Retrieved from http://oha.inl.gov:7777/pls/apex/f?p=101:HOME 
Cork, S. (Ed.). 2010. Resilience and transformation: preparing Australia for uncertain futures (1, 2, 15). CSIRO Publishing.

Cosgrave, J., et al. 2007. Inter-agency real-time evaluation of the response to the February 2007 floods and cyclone in Mozambique. Report for UN System.

Ecotrust. 2012. Resilience and Transformation: A Regional Approach, 2-50.

EcoWatch. 2016. How Is Climate Change Affecting the Philippines? The Climate Reality Project.

Ezra, M., and Kiros, G. E. 2001. Rural out-migration in the drought prone areas of Ethiopia: A multilevel analysis. International Migration Review, 749-771.

Federal Democratic Republic of Ethiopia. n.d. Ethiopia's Vision for a Climate Resilient Green Economy. Addis Ababa: Federal Democratic Republic of Ethiopia, Environmental Protection Authority.

Federal Democratic Republic of Ethiopia. 2007. Climate Change National Adaptation Program of Action (NAPA) of Ethiopia. Addis Ababa: Federal Democratic Republic of Ethiopia, Ministry of Water Resources and National Meteorological Agency.

Frankenberger, T. 2015. Ethiopia Pastoralist Areas Resilience Improvement and Market Expansion (PRIME) Project Impact Evaluation Report of the Interim Monitoring.

Field, C.B., et al. (eds.). 2014. Summary for policymakers. In: Climate Change 2014: Impacts, Adaptation, and Vulnerability. Part A: Global and Sectoral Aspects. Contribution of Working Group II to the Fifth Assessment Report of the Intergovernmental Panel on Climate Change. Intergovernmental Panel on Climate Change.

Field, C.B., et al. (eds.). 2014. Summaries, Frequently Asked Questions, and Cross-Chapter Boxes. In: Climate Change 2014: Impacts, Adaptation, and Vulnerability. A Contribution of Working Group II to the Fifth Assessment Report of the Intergovernmental Panel on Climate Change. Intergovernmental Panel on Climate Change.

Folke, C. 2006. Resilience: The emergence of a perspective for social-ecological systems analyses. Global environmental change, 16(3), 253-267.

Folke, C., et al. 2010. Resilience thinking: integrating resilience, adaptability and transformability. Ecology and Society, 15.

Gunderson, L. H. 2000. Ecological resilience--in theory and application. Annual review of ecology and systematics, 425-439.

Haile, M. 2005. Weather patterns, food security and humanitarian response in sub-Saharan Africa. Philosophical Transactions of the Royal Society B: Biological Sciences, 360(1463), 2169-2182.

Hallegatte, S. 2014. Economic Resilience: definition and measurement. World Bank Policy Research Working Paper, (6852).

Health in Harmony. Retrieved from http://www.healthinharmony.org

Holling, C. S. 1973. Resilience and stability of ecological systems. Annual review of ecology and systematics, 4, $1-23$.

International Disaster Database. n.d. Centre for Research on Epidemiology of Disasters. Retrieved from http:// www.emdat.be 
Intergovernmental Panel on Climate Change. 2014. Glossary of Terms used in the IPCC Fourth Assessment Report. Retrieved from http://www.ipcc.ch/pdf/glossary/ar4-wg2.pdf

Israel, D. C., and Briones, R. M. 2014. Disasters, Poverty, and Coping Strategies: The Framework and Empirical Evidence from Micro/Household Data-Philippine Case (No. DP 2014-06). Philippine Institute for Development Studies.

Janssen, M. A., et al. 2006. Toward a network perspective on the resilience of social-ecological systems. Ecology and Society, 11(1).

Keim, M. E. 2008. Building human resilience: the role of public health preparedness and response as an adaptation to climate change. American journal of preventive medicine, 35(5), 508-516.

Kidanu, A., Rovin, K., and Hardee, K. 2009. Linking population, fertility and family planning with adaptation to climate change: views from Ethiopia. Washington, DC: Population Action International.

Kois, Bethany. 2016. Phone interviews, July 14 and 20.

Kurniawan, L. et al. n.d. Redefining Community Resilience in Indonesia. Indonesian National Agency for Disaster Management. https://www.unisdr.org/campaign/resilientcities/assets/documents/privatepages/ Redefining\%20Community\%20Resilience\%20in\%20Indonesia.pdf. Accessed June 7, 2017.

Linnenluecke, M., \& Griffiths, A. 2010. Beyond adaptation: resilience for business in light of climate change and weather extremes. Business \& Society.

Mancini, J. A., and Bowen, G. L. 2009. Community resilience: A social organization theory of action and change. Pathways of human development: Explorations of change, 245-265.

Matsimbe, Z. 2003. Assessing the Role of Local Institutions in Reducing the Vulnerability of At-Risk Communities in Búzi, Central Mozambique. In: The Role of Local Institutions in Reducing Vulnerability to Recurrent Natural Disasters and in Sustainable Livelihoods Development.

Mayunga, J. S. 2007. Understanding and applying the concept of community disaster resilience: a capital-based approach. Summer academy for social vulnerability and resilience building, 1, 16.

Mercy Corps. 2015. Building Community Resilience during Violent Conflict, 1-11.

Mengistu, D. K. 2011. Farmers' perception and knowledge on climate change and their coping strategies to the related hazards: case study from Adiha, central Tigray, Ethiopia. Agricultural Sciences, 2(02), 138.

Mirza, M. M. Q. 2003. Climate change and extreme weather events: can developing countries adapt? Climate policy, 3(3), 233-248.

National Air and Space Administration. 2014. Earth Observatory. "Global Temperatures. "https:// earthobservatory.nasa.gov/Features/WorldOfChange/decadaltemp.php

National Biodefense Science Board. 2014. "National Biodefense Science Board Community Health Resilience Report.” Pp. 1-13. https://www.phe.gov/Preparedness/legal/boards/nprsb/meetings/Documents/nbsbchrreport.pdf. Accessed June 7, 2017.

Norris, F. H., et al. 2008. Community resilience as a metaphor, theory, set of capacities, and strategy for disaster readiness. American journal of community psychology, 41(1-2), 127-150.

Osbahr, H., Twyman, C., Adger, W. N., and Thomas, D. S. 2008. Effective livelihood adaptation to climate change disturbance: scale dimensions of practice in Mozambique. Geoforum, 39(6), 1951-1964. 
Pantuliano, S., and Wekesa, M. 2008. Improving drought response in pastoral regions of Ethiopia.

Porter, S. 2016. Can Indonesia’s forest fires be put out for good? BBC.

Pouligny, B. n.d. The Resilience Approach to Peacebuilding: A New Conceptual Framework. United States Institute of Peace.

Regassa, S., Givey, C., \& Castillo, G.E. 2010. The rain doesn't come on time anymore: poverty, vulnerability, and climate variability in Ethiopia. Oxfam International.

Resilience Alliance. Retrieved from http://www.resalliance.org/key-concepts

Sawada, Y., Estudillo, J. P., Fuwa, N, and Kajisa, K. 2009. How Do People Cope with a Natural Disaster? The Case of Super-Typhoon Milenyo in the Philippines. Development, Natural Resources and the Environment, 116150.

Schaar, J. 2014. Adaptation and Governance. Tetra Tech ARD, 1-18.

Schemm, P. 2016. History Repeats Itself in Ethiopia. The Washington Post.

Simmie, J., and Martin, R. 2010. The economic resilience of regions: towards an evolutionary approach. Cambridge journal of regions, economy and society, 3(1), 27-43.

Stiefel, J. 2016. "Building Community Health Resilience: The Community Health Resilience Initiative." PEPH Webinar on Climate Change and Health.” https://www.niehs.nih.gov/research/supported/translational/ peph/webinars/climate_change/stiefel_508.pdf

Tibig, L.V. 2003. Local Coping Strategies and Technologies for Adaptation in the Philippines. [Powerpoint slides]. Retrieved from https://unfccc.int/files/meetings/workshops/other_meetings/application/pdf/tibig.pdf

Tran, M. 2014. “Typhoon Haiyan Disaster Response: How the Relief Effort Worked.” https://www.theguardian. com/global-development/poverty-matters/2014/feb/07/typhoon-haiyan-disaster-response-philippinesrelief-effort

UN Country Team in Mozambique. 2015. Mozambique Floods 2015 Response and Recovery Proposal.

UNDP. 2015a. Brief note for countries in the 2015 Human Development Report: Mozambique. In: Human Development Report 2015.

UNDP. 2015b. Brief note for countries in the 2015 Human Development Report: Philippines. In: Human Development Report 2015.

UNDP. 2015c. Indonesia government addresses deforestation challenges in its aim to double palm oil production by 2020 .

US Department of Health and Human Services. (2009). National Health Security Strategy of the United States of America. Washington, DC: US Department of Health and Human Services.

Uy, N., Takeuchi, Y., and Shaw, R. 2011. Local adaptation for livelihood resilience in Albay, Philippines. Environmental Hazards, 10(2), 139-153.

World Bank. 2015. "Indonesia's Fire and Haze Crisis.” Feature Story. http://www.worldbank.org/en/news/ feature/2015/12/01/indonesias-fire-and-haze-crisis. Accessed June 7, 2017. 
Wunder, S., et al. 2008. When donors get cold feet: the community conservation concession in Setulang (Kalimantan, Indonesia) that never happened. Ecology and Society: a journal of integrative science for resilience and sustainability, 13(1).

United Nations Framework Convention on Climate Change (UNFCCC). 2007. Climate Change: Impacts, Vulnerability, and Adaptation in Developing Countries, 1-64.

University Corporation for Atmospheric Research (UCAR). 2010. Chapter 7: Community-Based Disaster Management. In: Flash Flood Early Warning System Reference Guide.

USAID. 2012. Climate Change Adaptation in Mozambique. https://www.climatelinks.org/sites/default/files/ asset/document/mozambique_adaptation_fact_sheet_feb2012.pdf. Accessed May 25, 2017.

Vogus, T. J., \& Sutcliffe, K. M. 2007. Organizational resilience: towards a theory and research agenda. In 2007 IEEE International Conference on Systems, Man and Cybernetics (pp. 3418-3422). October. IEEE.

Walker, B., Holling, C. S., Carpenter, S. R., \& Kinzig, A. 2004. Resilience, adaptability and transformability in social--ecological systems. Ecology and society, 9(2), 5. Natural Hazards and Earth System Sciences, 13(11), 2707-2716.

Waller, M. A. 2001. Resilience in ecosystemic context: evolution of the concept. American Journal of Orthopsychiatry, 71(3).

Werner, E. E. 1995. Resilience in development. Current directions in psychological science, 4(3), 81-85.

White, E. and White, R. 2012. Mozambique: Disaster Risk Financing and Insurance Country Note.

White, M. 2013. Building a Resilient Organizational Culture, 1-13. UNC Kenan-Flagler Business School.

Zhou, H., Wang, J., Wan, J., \& Jia, H. 2010. Resilience to natural hazards: a geographic perspective. Natural Hazards, 53(1), 21-41. 
evidenceproject.popcouncil.org

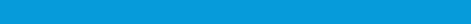

政

evidenceproject.popcouncil.org

$x^{2}$ 